\title{
THE EFFECT OF FIBROBLAST GROWTH FACTOR ON PC12 CELLS ${ }^{1}$
}

\author{
AKIFUMI TOGARI, GENEVA DICKENS, HIROSHI KUZUYA, AND GORDON GUROFF ${ }^{2}$ \\ Section on Growth Factors, National Institute of Child Health and Human Development, National Institutes of Health, \\ Bethesda, Maryland 20205
}

Received January 24, 1984; Revised July 9, 1984; Accepted August 27, 1984

\begin{abstract}
PC12 cells, which differentiate morphologically and biochemically into sympathetic neuron-like cells when treated with nerve growth factor, also respond to fibroblast growth factor. Some of the changes induced by fibroblast growth factor are similar to those seen after nerve growth factor treatment.

Specifically, pituitary fibroblast growth factor causes the formation of processes initially comparable to those produced by nerve growth factor. However, in contrast to the outgrowth induced by nerve growth factor, which continues for several days, the outgrowth of processes induced by fibroblast growth factor ceases after about 3 days, even though fresh fibroblast growth factor is added. After about 6 days the processes induced by fibroblast growth factor have virtually disappeared. In this regard the processes induced by fibroblast growth factor are very similar to those induced by dibutyryl cyclic adenosine $3^{\prime}: 5^{\prime}$-monophosphate (dBcAMP). The addition of nerve growth factor and fibroblast growth factor together appears to produce a synergistic effect on process formation, as does the simultaneous addition of nerve growth factor and dBcAMP. Cells pretreated (or primed) with nerve growth factor are able to regenerate processes much more rapidly in the presence of nerve growth factor than cells which have not been pretreated. When fibroblast growth factor is added to cells primed with nerve growth factor, more rapid regeneration of processes also occurs. The regeneration of neurites in response to either factor is blocked by the addition of an inhibitor of methylation.

The process formation induced by fibroblast growth factor is preceded, as is the outgrowth in response to nerve growth factor treatment, by an induction of ornithine decarboxylase, a decrease in the phosphorylation of a specific cytoplasmic protein, and an increase in the phosphorylation of a specific non-histone nuclear protein. The effects of fibroblast growth factor and of nerve growth factor on ornithine decarboxylase are additive. Fibroblast growth factor does not cause an increase in the activity of acetylcholinesterase; nerve growth factor does.

Fibroblast growth factor does not appear to be acting through the nerve growth factor receptor. The binding of iodinated nerve growth factor to PC12 cells is specific and is not inhibited by the presence of fibroblast growth factor. In addition, anti-nerve growth factor serum does not interfere with the action of fibroblast growth factor.

The use of highly purified fibroblast growth factor indicates that fibroblast growth factor is, on a molecular basis, at least as active as nerve growth factor for PC12 cells.
\end{abstract}

The PC12 cell, a clone derived from a pheochromocytoma tumor of the rat adrenal medulla, has become the premiere model for the study of the actions of nerve growth factor (NGF). In the presence of NGF in nanomolar quantities, the tumor line undergoes profound morphological electrophysiological, and biochemical alterations (Greene and Tischler, 1976, 1982; Dichter et al., 1977; Greene and Rein, 1977; Guroff, 1984). Among the latter is the induction of a number proteins, including some of the cnzymes involved in the metabolism of neurotransmitters (Greene and Rein, 1977; Schubert et al.,

\footnotetext{
${ }^{1}$ We wish to acknowledge the help of Drs. Denis Gospodarowicz and Lloyd Greene. Dr. Gospodarowicz provided advice on the use of fibroblast growth factor, shared his results prior to their publication, and sent a generous gift of highly purified pituitary fibroblast growth factor. Dr. Greene contributed helpful comments and also shared his as-yetunpublished data.

${ }^{2}$ To whom correspondence should be addressed.
}

1977; Lucas et al., 1979, 1980; Rieger et al., 1980). These changes, in toto, approximate the conversion of chromaffin cells into sympathetic neurons. The mechanism by which these changes occur is not known in detail, but it is thought that the factor acts at the membrane and, perhaps, through some series of second messengers (Heumann et al., 1981), at the nucleus also (Bradshaw, 1978). These nuclear actions are transcriptionally based and may be mediated by changes in cytoplasmic and nuclear phosphorylation (Halegoua and Patrick, 1980; Yu et al., 1980; End et al., 1983).

In addition to the use of this system for studies on NGF, it is widely viewed as a relevant model for the investigation of neuronal differentiation. Because of the increasing use of this cell system, it is important to know which of the various effectors act on it. As indicated above, these cells are sensitive to NGF. The cells also respond to epidermal growth factor (Guroff ct al., 1981a; Huff et al., 1981), tumor promoters (End et al., 1982), adenosine analogues (Guroff et al., 1981b), and cAMP derivatives (Gunning et al., 1981). The actions of these 
Control

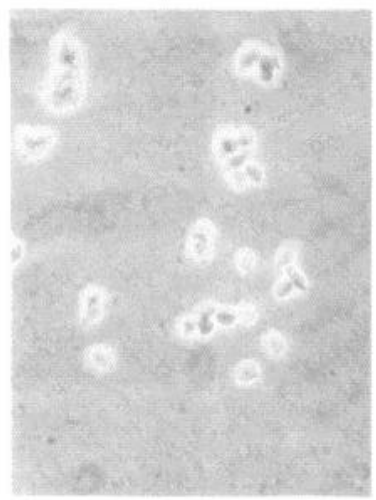

1 Day

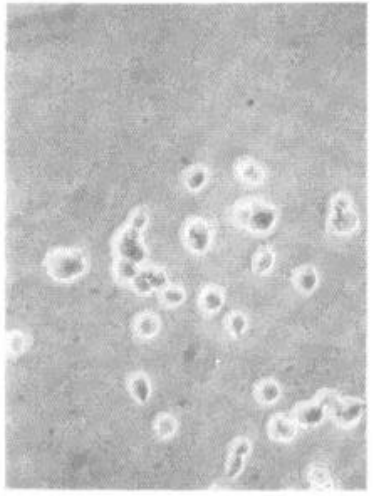

3 Days
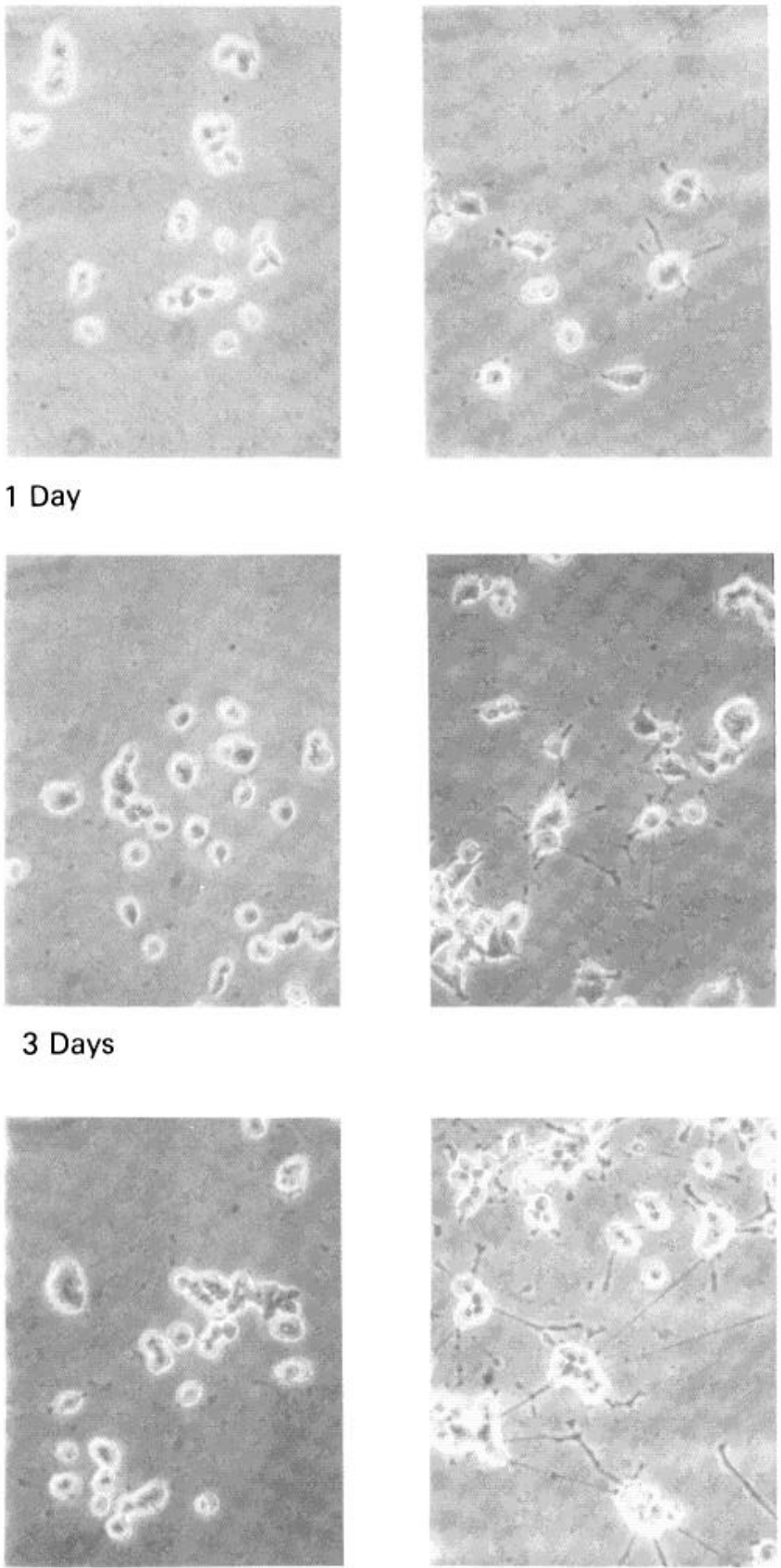

FGF
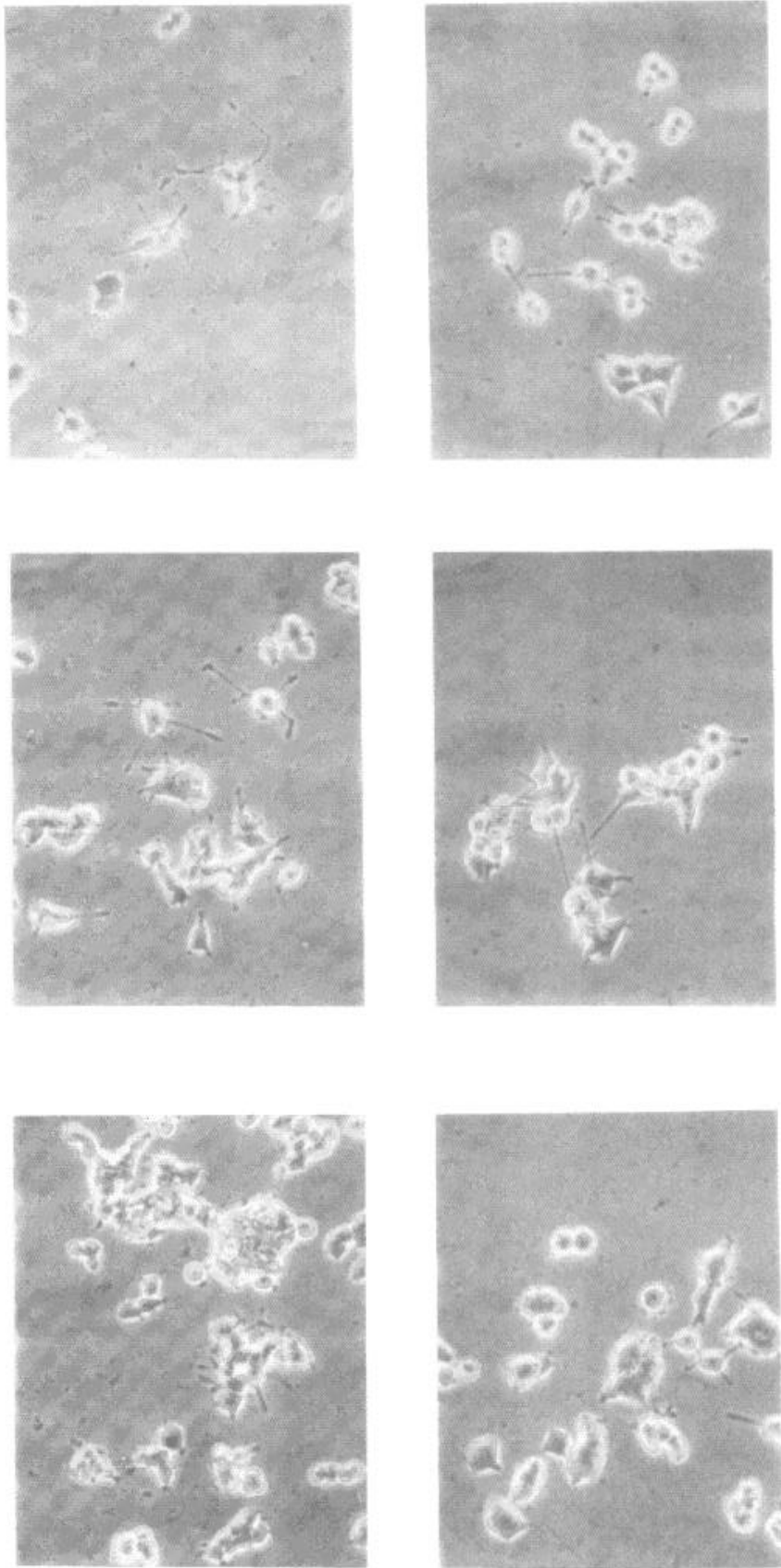

6 Days

Figure 1. Process formation in PC12 cells induced by NGF, FGF, or dBcAMP. Cells were treated with $50 \mathrm{ng} / \mathrm{ml}$ of NGF, $50 \mathrm{ng} / \mathrm{ml}$ of FGF, or $0.5 \mathrm{~mm}$ dBcAMP for 6 days. Culture medium containing each additive was changed every other day.

other effectors are the same in some cases as those of NGF. However, none of these several other agents produces the single most characteristic action of NGF, namely, neurite outgrowth. Recently, we have reported (Togari et al., 1983) that fibroblast growth factor (FGF), a partially purified material from either brain or pituitary with mitogenic actions on a number of cell types, primarily those of mesodermal origin, induces process formation in PC12 cells. Thus, it appeared that two peptides, NGF and FGF, derived from quite different sources, and with quite different chemical structures, might have similar morphological effects on PC12 cells.

In this report, we compare the actions of NGF and FGF on process formation, the induction of ornithine decarboxylase, and specific cytoplasmic and nuclear phosphorylations. In addition, we present evidence for the presence of independent FGF receptors on PC12 cells. Finally, we include data obtained with highly purified preparations of FGF showing that FGF is, in fact, at least as potent on a molar basis as is NGF.

\section{Materials and Methods}

Cell culture. PC12 cells were maintained as monolayers in $150-\mathrm{cm}^{2}$ plastic tissue culture flasks. The cells were grown in Dulbecco's modified Eagle's medium (Grand Island Biological Co., Grand Island, NY) supplemented with $7 \%$ fetal bovine serum, $7 \%$ horse serum, and 100 $\mu \mathrm{g}$ of streptomycin and 100 units of penicillin/ml (HEM Research Inc., Rockville, MD), and were kept at $37^{\circ} \mathrm{C}$ in a humidified $6 \% \mathrm{CO}_{2}$ 

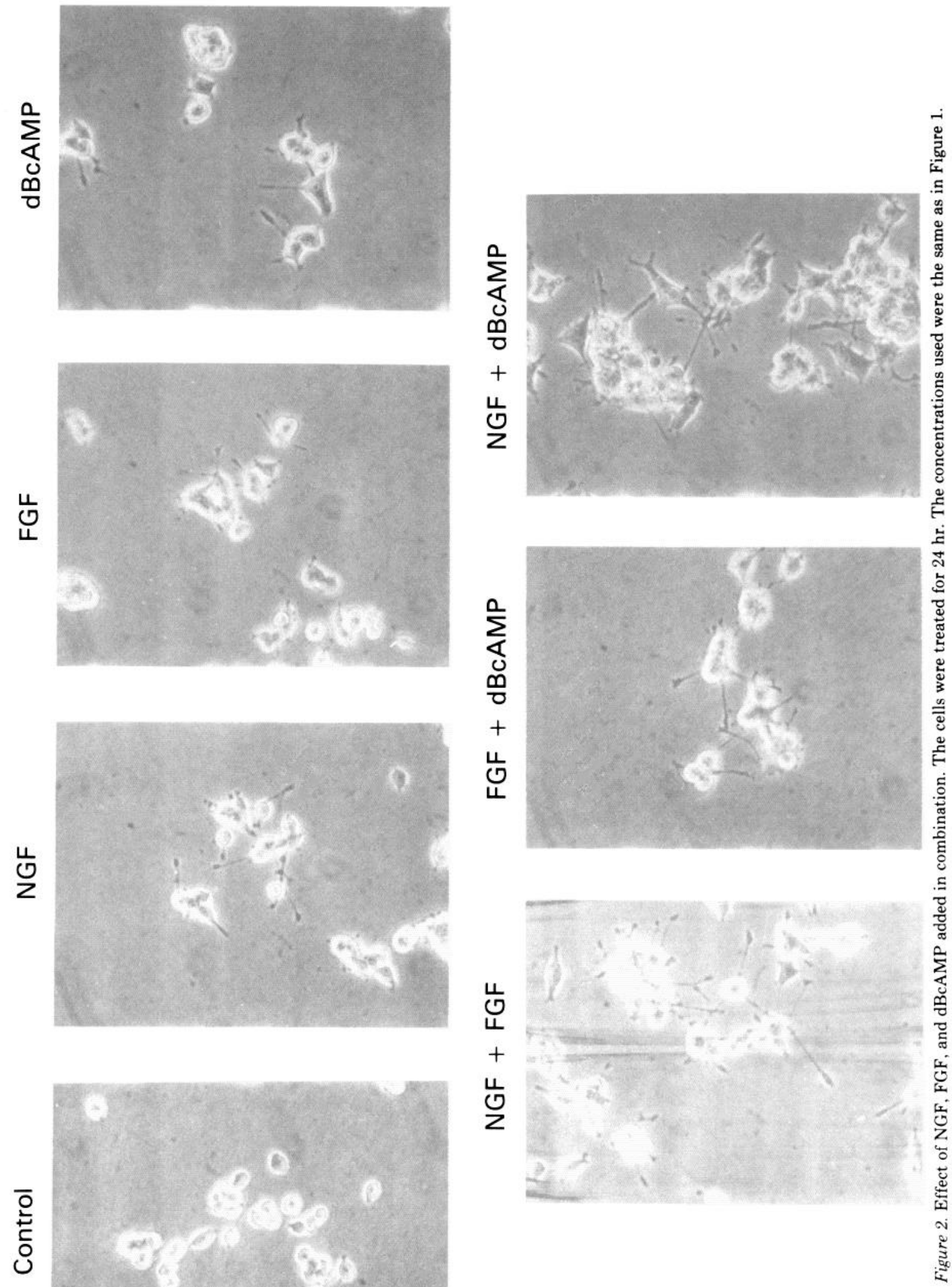


\section{Unprimed Cells}

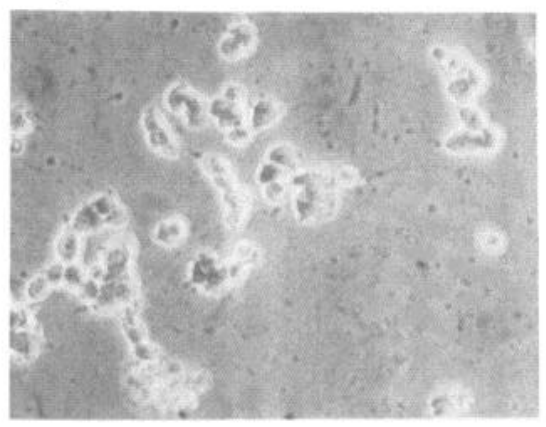

\section{Cells Primed with NGF}
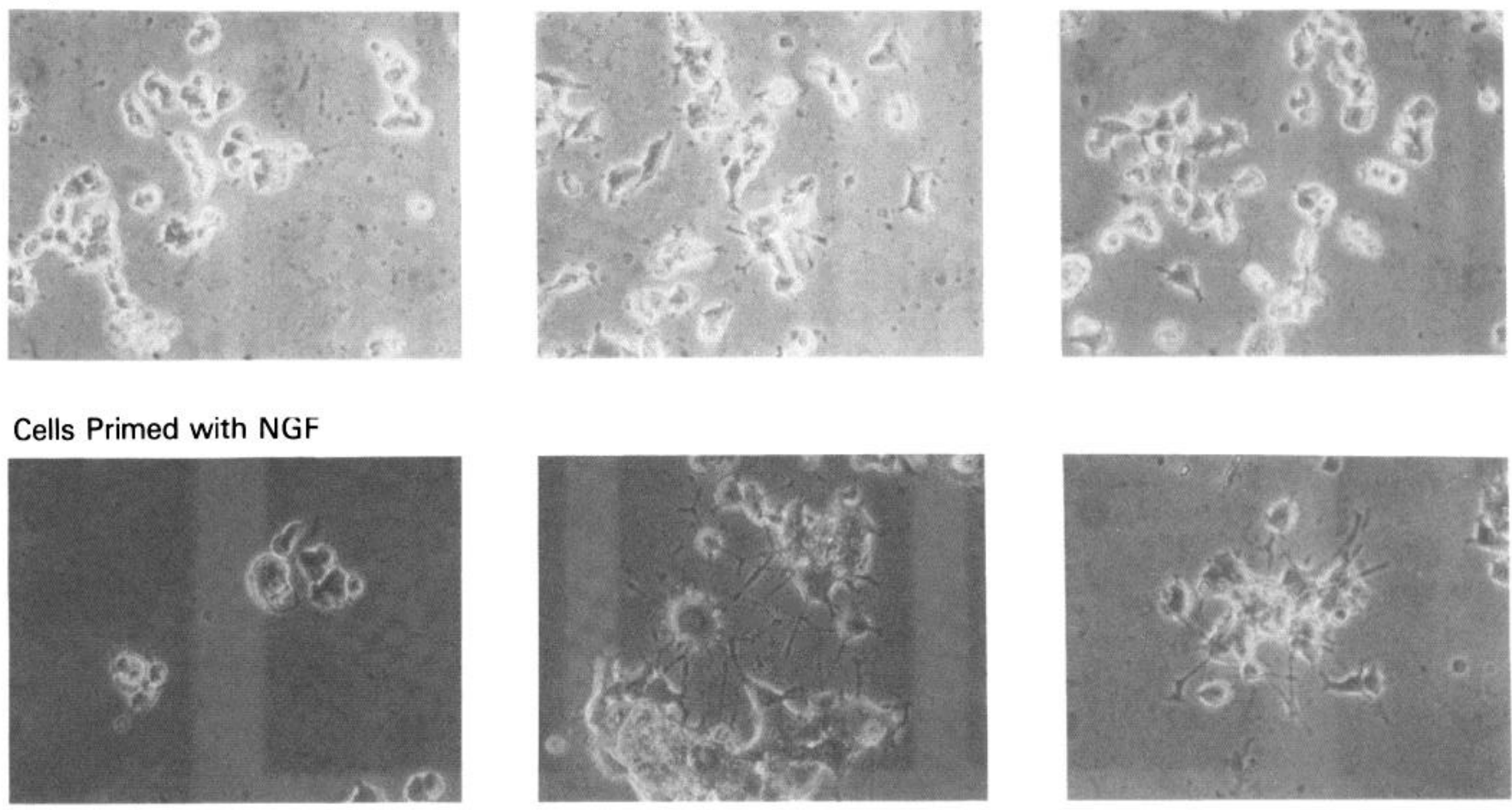

\section{Cells Primed with FGF}
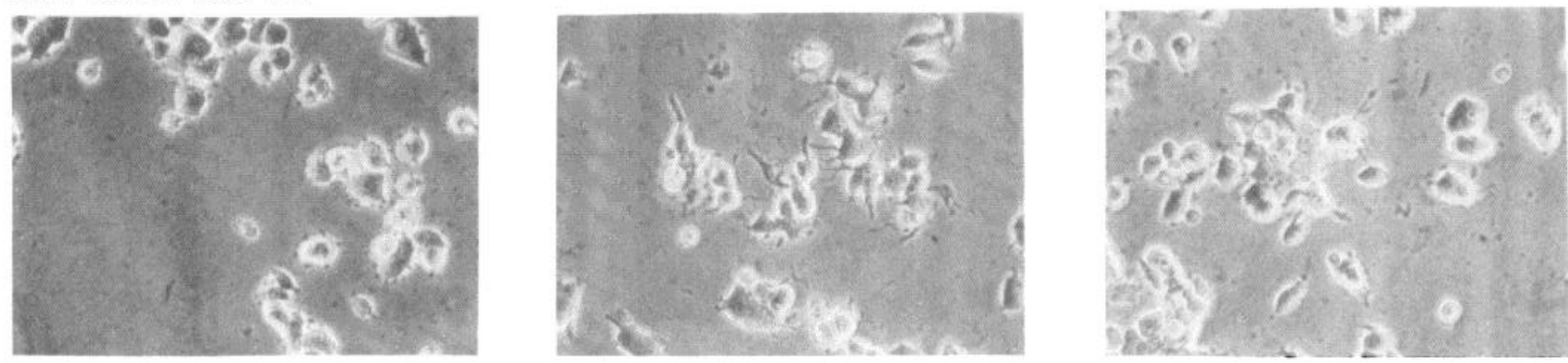

Control

NGF

FGF

Figure 3. Effect of NGF and FGF on PC12 cells primed with NGF. Cells were treated with NGF for 7 days, triturated to shear off neurites, and then replated for 1 day in the presence of NGF or pituitary FGF.

incubator. The medium was changed twice a week and the cells were generally split once a week in a 1:4 or 1:6 ratio. For the evaluation of priming, the cells were treated with pituitary FGF or NGF for 7 days. The cells were rinsed gently with culture medium and then were dislodged by shaking in fresh medium, thus shearing off the processes. They were replated for 1 day in the presence of pituitary FGF or NGF. In these experiments, fresh NGF or FGF was added to culture medium every other day.

Enzyme assay. Ornithine decarboxylase levels were measured by the method of Pegg and Williams-Ashman (1968) as modified by Oka and Perry (1976). The cells were treated in the flasks with FGF or NGF for $5 \mathrm{hr}$, after which the medium was removed by aspiration and the cells were dislodged by shaking in $10 \mathrm{ml}$ of $0.32 \mathrm{M}$ sucrose containing $1 \mathrm{mM}$ sodium phosphate, $\mathrm{pH} 6.5,1 \mathrm{mM} \mathrm{MgCl}_{2}$, and $3 \mathrm{mM} \mathrm{CaCl}$. The cells were collected by centrifugation, washed twice with the same buffer, and then suspended in $200 \mu \mathrm{l}$ of a homogenizing buffer containing 50 $\mathrm{mm}$ Tris- $\mathrm{HCl}, \mathrm{pH} 7.5,5 \mathrm{~mm}$ dithiothreitol, and $40 \mu \mathrm{M}$ pyridoxal phosphate. The suspension was frozen on dry ice and stored at $-20^{\circ} \mathrm{C}$. In preparation for the ornithine decarboxylase assay, the suspension was thawed, homogenized in an all-glass homogenizer, and centrifuged for $20 \mathrm{~min}$ at $10,000 \times \mathrm{g}$. The incubation mixture consisted of the cell supernatant fraction, usually $50 \mu \mathrm{l}$, diluted to $250 \mu \mathrm{l}$ with the homoge- nizing buffer; $200 \mu \mathrm{l}$ of an incubation buffer containing $125 \mathrm{mM}$ Tris$\mathrm{HCl}, \mathrm{pH} 7.5,100 \mu \mathrm{M}$ pyridoxal phosphate, $12.5 \mathrm{mM}$ dithiothreitol, and $10 \mathrm{mM}$ ethylenediaminetetra-acetic acid; $25 \mu \mathrm{l}(1.25 \mu \mathrm{Ci})$ of substrate, L- $\left[1-{ }^{14} \mathrm{C}\right]$ ornithine monohydrochloride $(58 \mathrm{mCi} / \mathrm{mmol}$ ) (Amersham Corp., Arlington Heights, IL); and $25 \mu \mathrm{l}$ of water. The reaction was carried out in rubber-stoppered tubes with hanging center wells. Each well contained $200 \mu$ l of Hyamine hydroxide to absorb the labeled $\mathrm{CO}_{2}$. The reaction was allowed to proceed for $1 \mathrm{hr}$ at $37^{\circ} \mathrm{C}$ and was then terminated by the injection of $0.6 \mathrm{ml}$ of $2.5 \mathrm{M} \mathrm{H}_{2} \mathrm{SO}_{4}$ through the stopper into the mixture. The tubes were allowed to equilibrate at room temperature for $2 \mathrm{hr}$; then the Hyamine-containing center well was placed in a scintillation vial containing Liquifluor, and the radioactivity was measured in a liquid scintillation spectrometer.

Acetylcholinesterase was measured by the method of Johnson and Russell (1975). The cells were treated with each factor for 3 days, after which the cells were collected as indicated above for the assay of ornithine decarboxylase and were suspended in $200 \mu \mathrm{l}$ of $5 \mathrm{~mm}$ Tris$\mathrm{HCl}, \mathrm{pH} 7.5$, containing $0.1 \%$ Triton $\mathrm{X}-100$. The suspensions were frozen on dry ice and kept at $-20^{\circ} \mathrm{C}$ until assayed. The suspensions were thawed, homogenized in an all-glass homogenizer, and centrifuged at $8000 \times g$ for $15 \mathrm{~min}$. A portion of the supernatant fraction, usually $15 \mu \mathrm{l}$, was used for the assay. The incubations were performed in small 


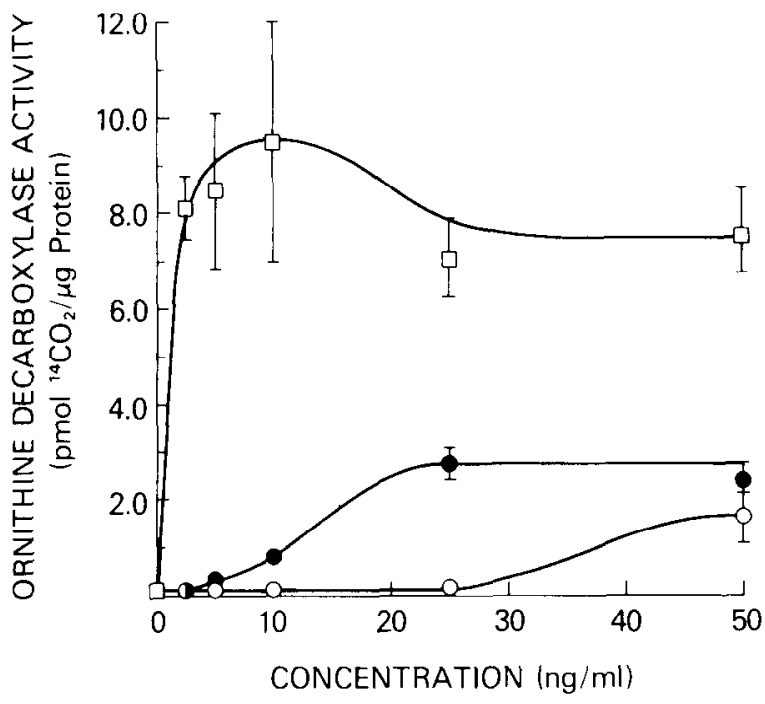

Figure 4. Dose response curve of the induction of ornithine decarboxylase in PC12 cells by NGF and FGF. Cells were grown for $5 \mathrm{hr}$ in various concentrations of each factor. Each point represents the mean of three determinations. Error bars indicate SEM. Basal activity of ornithine decarboxylase was $0.125 \pm 0.051 \mathrm{pmol}$ of ${ }^{14} \mathrm{CO}_{2} / \mu \mathrm{g}$ of protein. $\square$, NGF; $\bullet$, pituitary FGF; O, brain FGF.

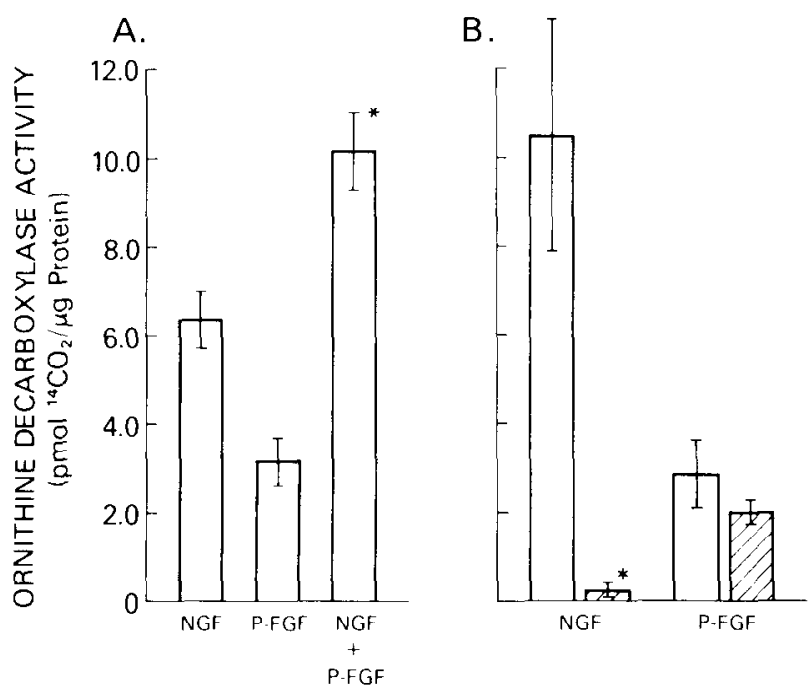

Figure 5. Influence of NGF or anti-NGF serum on ornithine decarboxylase induction in PC12 cells by FGF. A, Effect of NGF $(50 \mathrm{ng} / \mathrm{ml})$ on ornithine decarboxylase induction by pituitary FGF ( $P-F G F)(50$ $\mathrm{ng} / \mathrm{ml}$ ). Each bar represents the mean of eight determinations. Error bars indicate SEM. Basal activity of ornithine decarboxylase was 0.112 $+0.022 \mathrm{pmol}$ of ${ }^{14} \mathrm{CO}_{2} / \mu \mathrm{g}$ of protein. $B$, Effect of anti-NGF sheep serum $(20 \mu \mathrm{l} / \mathrm{ml})$ on ornithine decarboxylase induction by NGF $(50 \mathrm{ng} / \mathrm{ml})$ or pituitary FGF $(50 \mathrm{ng} / \mathrm{ml})$. Open bars, without antiserum; hatched bars, with antiserum. Each bar represents the mean of three determinations. Error bars indicate SEM. Basal activity of ornithine decarboxylase was $0.545 \pm 0.068 \mathrm{pmol}$ of ${ }^{14} \mathrm{CO}_{2} / \mu \mathrm{g}$ of protein. *, Statistical difference between $(A) \mathrm{NGF}$ and NGF + P-FGF and $(B)$ with-antiserum and without-antiserum groups $(p<0.05)$, calculated according to the Student's $t$ test.

counting vials which contained, in addition to the sample, $50 \mu$ l of 0.05 M phosphate buffer, $20 \mu \mathrm{l}$ of $20 \mathrm{mM}$ acetylcholine containing $1 \mu \mathrm{Ci}$ of [acetyl ${ }^{3} \mathrm{H}$ ] acetylcholine $(90 \mathrm{mCi} / \mathrm{mmol}$ ) (New England Nuclear, Boston, MA), and $15 \mu \mathrm{l}$ of water. The reaction was allowed to proceed for $10 \mathrm{~min}$ at room temperature and was stopped by the addition of $100 \mu \mathrm{l}$ of a "stopping solution" containing $1 \mathrm{~mm}$ chloroacetic acid and $2 \mathrm{M}$ $\mathrm{NaCl}$, adjusted to $\mathrm{pH} 2.5$ with $\mathrm{NaOH}$. Liquifluor (4 ml) and isoamyl alcohol $(0.4 \mathrm{ml})$ were added. The vials were capped and shaken vigor- ously, and the radioactivity was measured in a liquid scintillation spectrometer.

Phosphorylation in intact cells. Monolayers of $\mathrm{PC} 12$ cells were treated for $4 \mathrm{hr}$ with FGF or with NGF. $\left[{ }^{32} \mathrm{P}\right]$ Orthophosphate $(250 \mu \mathrm{Ci} / \mathrm{ml})$ (ICN Pharmaceuticals, Irvine, CA) was added to each flask during the final $2 \mathrm{hr}$ of incubation. After the incubation, the medium was removed and the cells were detached by shaking the flasks with ice-cold $0.32 \mathrm{M}$ sucrose containing $1 \mathrm{~mm}$ sodium phosphate buffer, $\mathrm{pH} 6.5,1 \mathrm{~mm}$ $\mathrm{MgCl}_{2}$, and $3 \mathrm{mM} \mathrm{CaCl}$. The cells were collected by centrifugation and rinsed twice with the same buffer.

To get the cytoplasmic protein, the cell pellet was taken up in $1 \mathrm{ml}$ of a medium consisting of $100 \mathrm{mM}$ 1,4-piperazine diethanesulfonic acid, pH 6.9, containing $1 \mathrm{mM} \mathrm{MgSO}, 2$ mM EGTA, and $0.1 \mathrm{mM} \mathrm{Na}_{2} \mathrm{MoO}_{4}$, and was homogenized in an all-glass homogenizer. The homogenates were centrifuged at $100,000 \times g$ for $1 \mathrm{hr}$. SDS sample buffer (Laemmli, 1970) was added to a portion of the ${ }^{32} \mathrm{P}$-labeled supernatant fraction and the sample was heated for $10 \mathrm{~min}$ at $90^{\circ} \mathrm{C}$. To get the nuclear protein, the cell pellet was taken up in $1 \mathrm{ml}$ of the sucrose buffer and was rehomogenized. The homogenates were centrifuged at $750 \times g$ for $10 \mathrm{~min}$, and the pellets were suspended in the same sucrose buffer containing $0.2 \%$ Triton $\mathrm{X}-100$. The suspension was homogenized and the centrifugation was repeated. The pellets were suspended once again in the sucrose buffer and layered on discontinuous sucrose gradients composed of portions of $0.8,1.2$, and $2.4 \mathrm{M}$ sucrose, all brought to the ionic composition of the original sucrose buffer. These gradients were centrifuged at $58,400 \times g$ for $1 \mathrm{hr}$. The ${ }^{32} \mathrm{P}$-labeled pellet was suspended in SDS sample buffer and the sample was heated for $10 \mathrm{~min}$ at $90^{\circ} \mathrm{C}$.

The sample from cytoplasmic or nuclear protein was examined by electrophoresis on $7.5 \%$ or $10 \%$ SDS/polyacrylamide gels, respectively. In order to place approximately equal amounts of total incorporated radioactivity in each of the sample walls for electrophoresis, the trichloroacetic acid-precipitable radioactivity of each sample was determined (Huang and Robinson, 1976). The SDS/polyacrylamide slab gels were prepared as described by O'Farrell (1975). The electrophoresis was carried out in SDS running buffer at $120 \mathrm{~V}$ for $4 \mathrm{hr}$. The gels were stained overnight with Coomassie brilliant blue staining solution and then were destained, initially with $40 \%$ ethanol/7\% acetic acid, and finally with $7 \%$ acetic acid. Molecular weights were estimated using standard proteins from Bio-Rad Laboratories (Richmond, CA). The gels were exposed to Kodak XR-5 film at room temperature, using an intensifying screen (DuPont Cronex Lighting Plus XA). The film was developed by standard procedures and scanned in a Zeineh Soft Laser Scanning Densitometer (LKB Instruments, Inc., Gaithersburg, MD).

Binding studies. Radioiodination of NGF was performed by the lactoperoxidase technique described in Bio-Rad Laboratories Technical Bulletin No. 1071 utilizing the Enzymobead solid phase enzyme reagent (Bio-Rad Laboratories, Richmond, CA). NGF (10 to $20 \mu \mathrm{g}$ ) was added to $75 \mu \mathrm{l}$ of $0.5 \mathrm{M}$ phosphate buffer, $\mathrm{pH} 7.2$. Then, $50 \mu \mathrm{l}$ of the rehydrated Enzymobeads and $25 \mu \mathrm{l}$ of $2 \%$ D-glucose were added, followed by $20 \mu \mathrm{l}$ of $\mathrm{Na}^{125} \mathrm{I}(2.0 \mathrm{mCi})$ (New England Nuclear). The mixture was kept for $45 \mathrm{~min}$ at room temperature. The reaction was terminated by centrifugation in a benchtop centrifuge; then, $50 \mu \mathrm{l}$ of $10 \mathrm{mM}$ tyrosine, $45 \mu \mathrm{l}$ of the equilibration buffer $(137 \mathrm{~mm} \mathrm{NaCl}, 2.6 \mathrm{~mm} \mathrm{KCl}, 1.0 \mathrm{~mm} \mathrm{CaCl}$, $0.1 \%$ glucose, $38 \mathrm{~mm} \mathrm{HEPES}, 38 \mathrm{mM} \mathrm{NaH}_{2} \mathrm{PO}_{4}$, and $0.1 \%$ bovine serum albumin), and $5 \mu \mathrm{l}$ of $10 \%$ phenol red were added to the supernatant fraction. The mixture was placed on a microcolumn prepared by the method of Tuszynski et al. (1980) to remove free $\mathrm{Na}^{125}$. The microcolumn was centrifuged, and the eluate was placed on a second column and centrifuged again. The procedure, if necessary, was repeated one or two times to remove all traces of phenol red from the eluate. In a typical preparation, $5 \mu \mathrm{l}$ of final eluate contained $3,250,000 \mathrm{cpm}$, which was $90 \%$ precipitable with $10 \%$ trichloroacetic acid.

The binding of NGF was measured by adding labeled factor to monolayer cultures of $\mathrm{PC} 12$ cells in fresh growth medium. The cells were incubated at $37^{\circ} \mathrm{C}$ for $45 \mathrm{~min}$, after which the radioactive medium was removed by aspiration. The monolayers were rinsed twice gently and rapidly with cold phosphate-buffered saline. Then, $2 \mathrm{ml}$ of $1 \mathrm{~N}$ $\mathrm{NaOH}$ were added to disrupt the monolayer, and the radioactivity contained in a $1-\mathrm{ml}$ portion was measured in a Searle model 1185 gamma counter (G. D. Searle Co., Des Plaines, IL).

Protein assay. Protein was usually determined by the method of Bradford (1976). When cell extracts were to be assayed for ornithine decarboxylase activity, a modification of the method of Lowry et al. (1951) was used in which the proteins were precipitated with $6 \%$ trichloroacetic acid in the presence of $0.0125 \%$ deoxycholate. 'The 

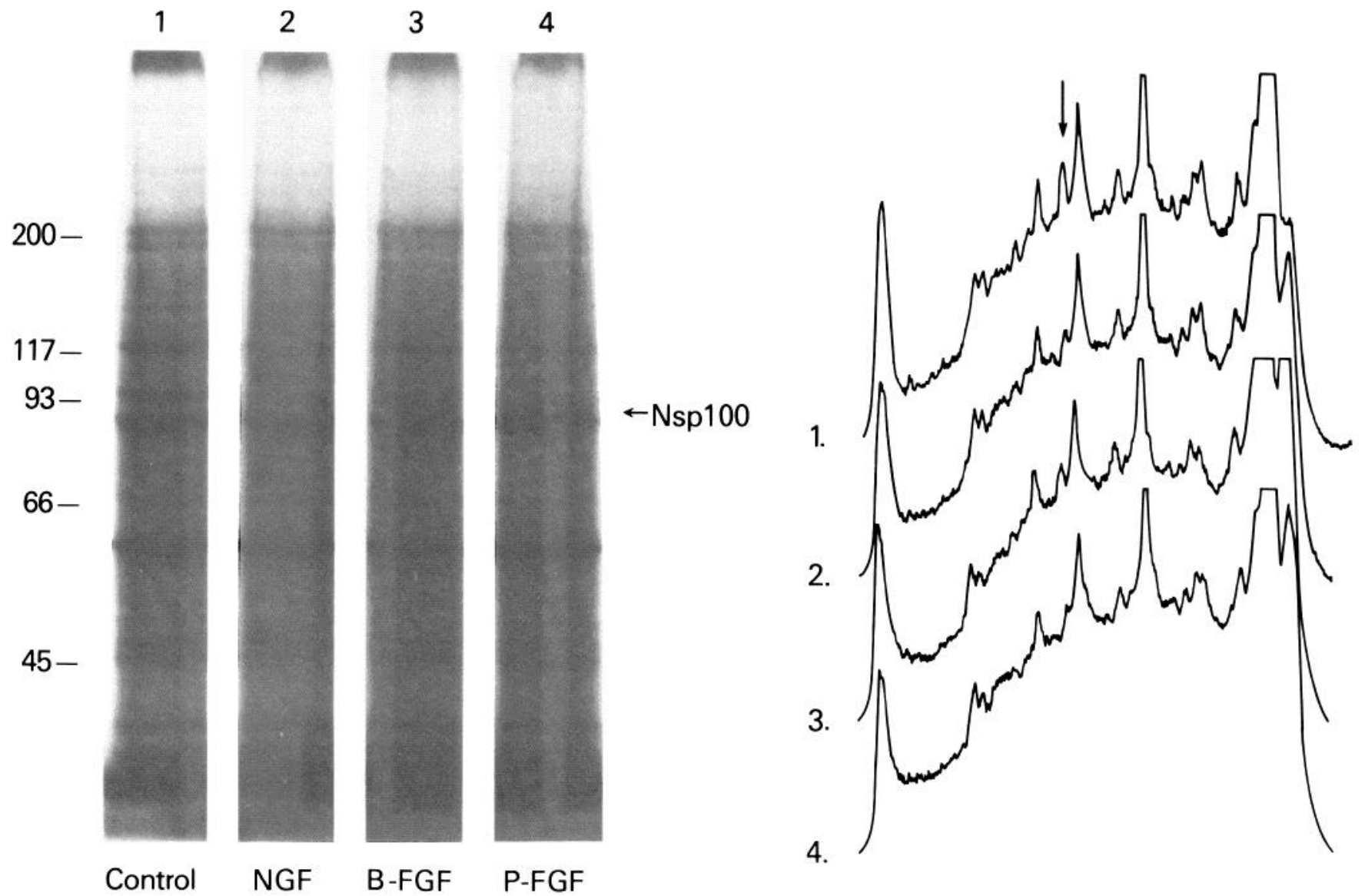

Figure 6. Effect of NGF and FGF on the phosphorylation of soluble proteins in PC12 cells. Cells were treated for 4 hr with $50 \mathrm{ng}$ of each factor $/ \mathrm{ml}$. After labeling with $\left[{ }^{32} \mathrm{P}\right]$ orthophosphate during the final $2 \mathrm{hr}$ of incubation, supernatants $(100,000 \times \mathrm{g})$ were prepared from the cells. The migration of standard marker proteins is indicated to the left of the autoradiogram, and the position of the NGF-sensitive protein (Nsp100),100,000 daltons, is shown by the arrows on both the autoradiogram and the tracing. $B-F G F$, brain FGF; $P-F G F$, pituitary FGF.

precipitated proteins were collected by centrifugation and dissolved in a reagent containing $0.017 \% \mathrm{CuSO}_{4}, 0.033 \%$ sodium/potassium tartrate, $1.6 \% \mathrm{Na}_{2} \mathrm{CO}_{3}, 0.13 \mathrm{M} \mathrm{NaOH}$, and $1.6 \%$ sodium dodecyl sulfate. After $10 \mathrm{~min}$, the samples were treated with $0.25 \mathrm{vol}$ of a $1: 3$ dilution of the commercial Folin reagent, and after $30 \mathrm{~min}$ the absorbance of the samples were determined at $750 \mathrm{~nm}$ in a spectrophotometer.

Materials. NGF was prepared by the method of Bocchini and Angeletti (1969). Anti-NGF serum was prepared in sheep by standard methods. FGFs were purchased from Collaborative Research (Lexington, MA) and from Bethesda Research Laboratories (Gaithersburg, MD). Highly purified pituitary FGF was a generous gift of Dr. Denis Gospodarowicz. 5'-Deoxy-5'-methylthioadenosine was obtained from Sigma Chemical Co. (St. Louis, MO).

\section{Results}

When PC12 cells were treated with FGF, processes began to form (Fig. 1). These processes were evident within $24 \mathrm{hr}$, and the amount of growth was dose dependent. Substantial outgrowth was observed at $25 \mathrm{ng}$ of $\mathrm{FGF} / \mathrm{ml}$. At $50 \mathrm{ng} / \mathrm{ml}$, a maximal level, the outgrowth was about the same as that produced by $50 \mathrm{ng} / \mathrm{ml}$ of NGF and by $0.5 \mathrm{~mm}$ dibutyryl cyclic AMP (dBcAMP). After 3 days of treatment, the cultures treated with the three agents, FGF, NGF, and dBcAMP still appeared comparable. By 6 days of treatment, however, the appearance of the cultures was quite different; those treated with NGF had profuse process outgrowth, whereas those treated with FGF or with $\mathrm{ABcAMP}$ were virtually without processes, in spite of the fact that all three agents had been added to the respective cultures every other day. Thus, the outgrowth of processes caused by FGF resembles that caused by dBcAMP, at least as far as the time course of appearance and disappearance is concerned. Pituitary FGF was more effective than brain FGF for this transient process outgrowth. The addition of comparable amounts of platelet-derived growth factor, $\mathrm{T}$ cell growth factor, or multiplication-stimulating activity was without effect.

It has been shown (Gunning et al., 1981) that dBcAMP and $\mathrm{NGF}$ are synergistic for process formation in PC12 cells. In this regard, also, FGF resembles dBcAMP. It can be seen (Fig. 2) that, when NGF and FGF were present together in the medium for $24 \mathrm{hr}$, process outgrowth was greater than with either alone. This was true of NGF and dBcAMP, but not of FGF and dBcAMP.

NGF-pretreated (or "primed") PC12 cells, divested of their processes by mechanical disruption, undergo regeneration of processes within $24 \mathrm{hr}$ of replating if NGF is present (Burstein and Greene, 1978; Greene et al., 1982) (Fig. 3). This regeneration is blocked by the addition of inhibitors of methylation (Seeley et al., 1983). When FGF was added to cells primed with $\mathrm{NGF}$, it caused regeneration of processes comparable to those produced by NGF (Fig. 3). But cells treated with FGF did not display enhanced process formation upon treatment with NGF (Fig. 3). The addition of $2 \mathrm{~mm} 5^{\prime}$-deoxy-5'-methylthioadenosine, an inhibitor of methylation, blocked neurite regeneration caused by either factor after priming by NGF.

FGF elicited a substantial increase in ornithine decarboxylase levels in PC12 cells (Fig. 4) $5 \mathrm{hr}$ after addition. Again, pituitary FGF was more potent than brain FGF. The increase was usually not as great as that produced by an equivalent amount of NGF. The addition of NGF and FGF together, at maximal concentrations of each, as shown before (Togari et al., 

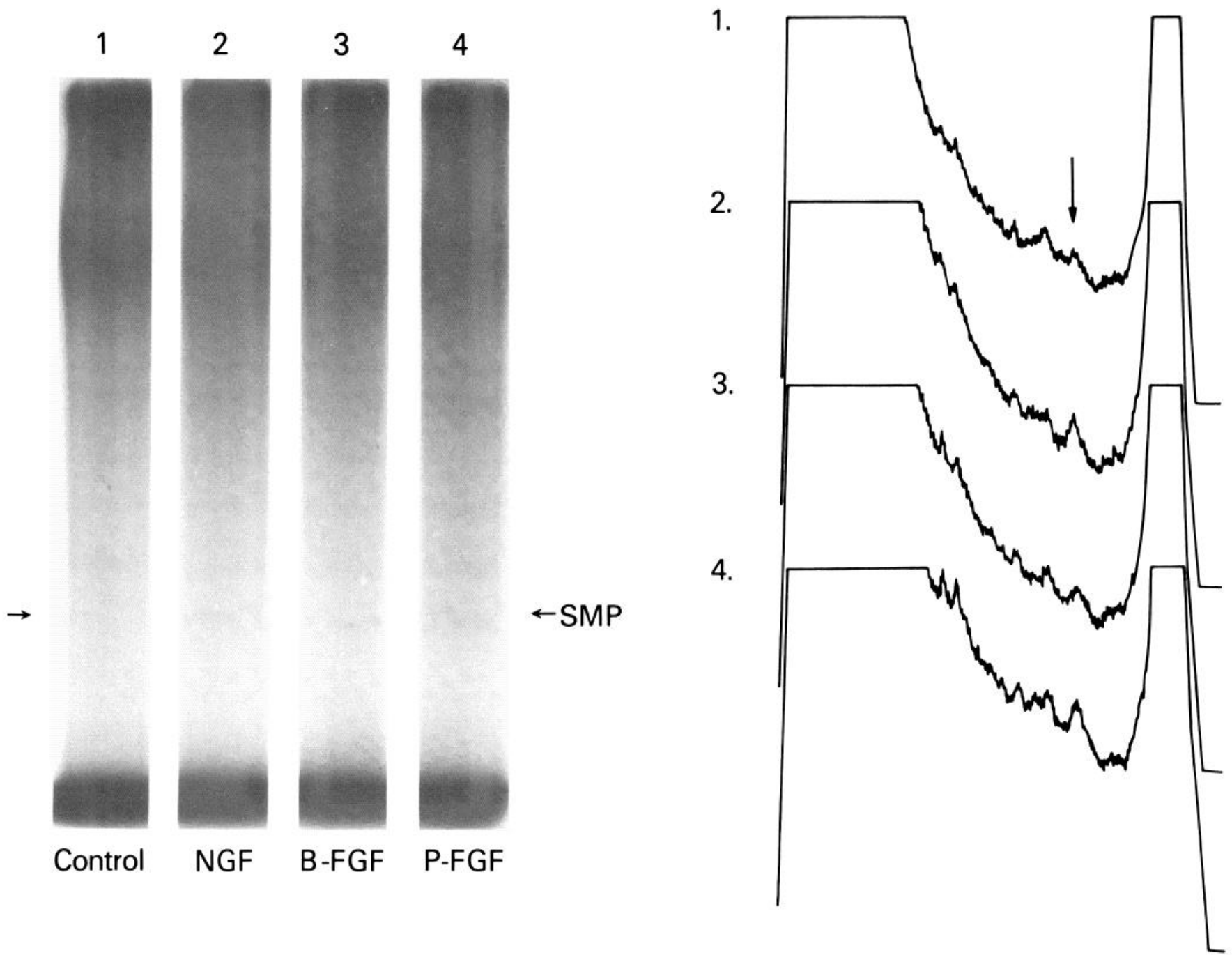

Figure 7. Effect of NGF and FGF on the phosphorylation of nuclear proteins in PC12 cells. Cells were treated for $4 \mathrm{hr}$ with $50 \mathrm{ng}$ of each factor $/ \mathrm{ml}$. After labeling with $\left[{ }^{32} \mathrm{P}\right]$ orthophosphate during the final $2 \mathrm{hr}$ of incubation, the nuclear fractions were prepared from the cells. The position of the slow migrating protein $(S M P)$ is shown by the arrows on both the autoradiogram and the tracing. $B-F G F$, brain $\mathrm{FGF}$; $P-F G F$, pituitary FGF.

1983), produced a greater increase in the enzyme than did either alone (Fig. 5A). Anti-NGF serum inhibited the action of NGF but had little or no effect on the action of FGF (Fig. $5 B$ ).

Treatment of the cells with FGF inhibited the phosphorylation of a specific cytoplasmic protein. The phosphorylation of this same protein is inhibited substantially and specifically by treatment with NGF (Fig. 6) (End et al., 1983). FGF also enhanced the phosphorylation of a specific non-histone protein in the nucleus. This protein is apparently the same one affected by treatment with NGF (Fig. 7) (Yu et al., 1980). The changes in phosphorylation in both cytoplasmic and nuclear proteins were more pronounced with pituitary than with brain FGF.

Acetylcholinesterase levels in PC12 cells, as reported by others (Lucas et al., 1980; Rieger et al., 1980), can be increased by a 72 -hr treatment with NGF. The addition of FGF had no effect on enzyme levels (Fig. 8).

To determine whether FGF action is mediated by unique receptors or by interaction of FGF with NGF receptors, binding experiments were performed. The binding of iodinated NGF to PC12 cells could be inhibited by the addition of unlabeled NGF (Table I). However, FGF did not displace labeled NGF. These data indicate that FGF does not interact with the NGF receptor on PC12 cells.
Highly purified FGF promotes outgrowth in a dose-dependent fashion. Processes were evident within $24 \mathrm{hr}$ in cultures treated with $5 \mathrm{ng}$ of $\mathrm{FGF} / \mathrm{ml}$ (Fig. 9).

\section{Discussion}

The characteristic morphological change in PC12 cells seen following NGF treatment, neurite outgrowth, has been the subject of substantial investigation since it is the hallmark of the differentiation and, of course, one of the most prominent and distinguishing features of neuronal growth. However, the mechanism by which NGF causes the cells to elaborate neurites is unknown. To understand the mechanism of neurite formation, it may be useful to be able to compare the actions of NGF with those of other agents which induce outgrowth. FGF, a mitogen for most cells upon which it acts, is such an agent. Thus, we have begin to characterize the actions of FGF on PC12 cells and to compare its actions with those of NGF.

Many of the actions of the two peptides appear quite similar. Thus, both NGF and FGF will induce process formation in PC12 cells. Both peptides will cause changes in the phosphorylation of specific proteins in the cells, and these changes are in the same direction. Also, both peptides will produce increases in the enzyme, ornithine decarboxylase. These biochemical 

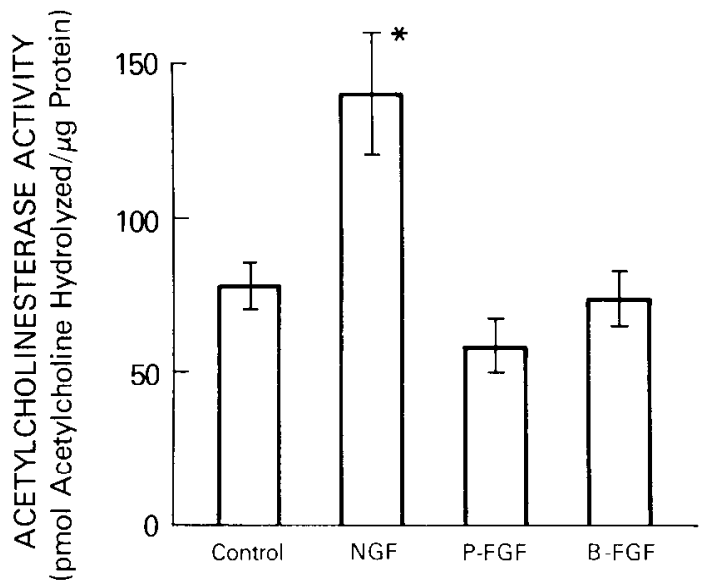

Figure 8. Effect of NGF and FGF on acetylcholinesterase levels in PC12 cells. Cells were treated with $50 \mathrm{ng} / \mathrm{ml}$ of each factor for $72 \mathrm{hr}$. Culture medium containing each factor was changed every other day. Each bar represents the mean of four determinations. Error bars indicate SEM. *, Statistical difference between control and treated groups $(p<0.05)$, calculated according to the Student's $t$ test. $B-F G F$, brain FGF; $P-F G F$, pituitary FGF.

\section{TABLE I}

The influence of NGF or FGF on the binding of $\left.\Gamma^{125} I\right] N G F$ to PC12 cells

\begin{tabular}{lccc}
\hline \multirow{2}{*}{ Additions } & \multirow{2}{*}{ Concentration } & \multicolumn{2}{c}{$\left[{ }^{125} \mathrm{~J}\right]$ NGF Bound } \\
\cline { 2 - 4 } & & Experiment 1 & Experiment 2 \\
\hline \multirow{3}{*}{ None } & $\mu g / m l$ & \multicolumn{2}{c}{$d p m / \mu g$ of cell protein } \\
NGF $^{b}$ & & $35.7 \pm 3.9^{\circ}$ & $47.4 \pm 9.2$ \\
& 125 & & $32.2 \pm 11.2$ \\
\multirow{3}{*}{ Pituitary FGF } & 250 & & $24.8 \pm 3.3$ \\
& 500 & $17.4 \pm 2.2$ & $22.5 \pm 1.2$ \\
& 125 & & $36.3 \pm 2.8$ \\
& 250 & & $55.8 \pm 21.3$ \\
& 500 & $36.6 \pm 7.5$ & $33.5 \pm 9.8$ \\
\hline
\end{tabular}

${ }^{a}$ Data are presented as mean $\pm \operatorname{SEM}(n=3)$.

${ }^{b}$ The concentration of $\left[{ }^{125} \mathrm{I}\right] \mathrm{NGF}$ in the incubations was 5 to $10 \mathrm{ng} /$ $\mathrm{ml}$.

changes, i.e., in phosphorylation and ornithine decarboxylase levels, are of unknown significance with regard to outgrowth. In fact, ornithine decarboxylase induction has been specifically dissociated from the process (Greene and McGuire, 1978). Nevertheless, the finding that these alterations are produced by FGF as well as by NGF does nothing to discourage further a consideration of them as participants in the eventual morphologic alterations.

Clearly, there are differences in the action of the two peptides. Process formation, although initially appearing similar, has a different time course. With NGF the processes continue to elongate and arborize for several days at least. With FGF this process formation stops after 2 or 3 days and, in spite of readditions of FGF, does not resume. In this regard, the action of FGF is very similar to that of $\mathrm{dBcAMP}$. Also, the induction of acetylcholinesterase, evident after $72 \mathrm{hr}$ of NGF treatment, does not occur after $72 \mathrm{hr}$ of FGF treatment. Thus, the shortterm effects of FGF on the cells are similar to those of NGF; the long-term effects appear different.

The similarity between the actions of FGF and those of $\mathrm{dBcAMP}$ is also seen in experiments in which these materials were added together with NGF. The actions of NGF and dBcAMP on outgrowth have been reported to be (Gunning et a., 1981), and are seen here to be, synergistic. This is also true for FGF and NGF. But the combination of FGF and ABcAMP does not seem to be even additive. This result is to be expected if FGF and dBcAMP are acting by the same mechanism. In a larger sense, the data suggest some involvement of cAMP in the actions of FGF.

The present data indicate that the addition of FGF to cells "primed" with NGF produces more short-term outgrowth than do comparable additions to unprimed cells. This may reflect the above conclusion, that FGF can mimic the short-term actions of NGF. Alternatively, it may merely reflect the synergism of a residual quantity of NGF with the fresh FGF. Whatever the reason, this action of FGF is also similar to the action of $\mathrm{ABcAMP}$ under similar conditions (Greene and Shooter, 1980).

The difference between the morphological actions of the two factors raises the question of whether the outgrowth seen with FGF should be termed "neurites." Although it is something of a semantic distinction, it may be useful to reserve the term neurites for the long, branched, fasiculated, and permanent processes produced by continued treatment with NGF. Since the extensions produced by FGF do not attain the length or the arborization seen with those induced by NGF, and surely do not have the permanence, they probably should not be termed neurites.

There is ample evidence presented here that FGF acts independently on the cells and neither contains a contaminant of NGF nor acts through the NGF receptor. In addition to the observed differences between the actions of the two peptides, there is: (1) the fact that the NGF antibody has no effect on FGF action; (2) the observation that, at least for ornithine decarboxylase action and probably for short-term outgrowth, the two factors are additive; (3) the finding that the binding of NGF to its receptor is not influenced by the presence of FGF; and, finally, (4) the consideration that puritied FGF is, on a molar basis, if anything, more active than NGF. Clearly, FGF acts on PC12 cells independently of, and probably additively with, NGF, and almost certainly through a separate receptor.

The fact that FGF appears to induce a form of differentiation in a neural-type cell raises several interesting points. As is well known, FGF is a potent mitogen for the cells on which it acts (Gospodarowicz, 1974, 1975; Gospodarowicz et al., 1978a); differentiating actions do not seem to have been reported. In addition, FGF has been used mostly for experiments on cells derived from the mesoderm (Grospodarowicz et al., 1978b); its action on cells of neural crest origin, such as the pheochromocytoma used here, has not been prominently observed. However, it is now clear that other growth factors also have at least dual actions. Epidermal growth factor, a potent mitogen, does alter phenotypic characteristics in certain cells under certain conditions (Johnson et al., 1980; Hsueh et al., 1981; White and Bancroft, 1983). Furthermore, NGF, known largely as an inducer of phenotypic characteristics, can be a mitogen for certain cells (Boonstra et al., 1983; Burstein and Greene, 1983). Thus, the present report can be added to the growing literature which suggests that the nature of the action of a given peptide may depend upon the cell on which it acts and upon the conditions under which it acts, in addition to the intrinsic properties of the factor itself.

Another aspect of FGF action dealt with here is the difference between the effectiveness of commercial preparations of the pituitary and the brain factors. Clearly, in this system, the pituitary FGF is more effective than the brain factor. Although neither preparation is homogeneous (and, as a consequence, each could contain impurities with unknown properties), the data suggest that the two factors are not identical. Similar data have been presented recently when more purified preparations of each factor were used to stimulate the growth of human umbilical vein cells (Gospodarowicz et al., 1983).

Some comment needs to be made regarding the significance of these observations for studies on NGF with the PC12 model. 

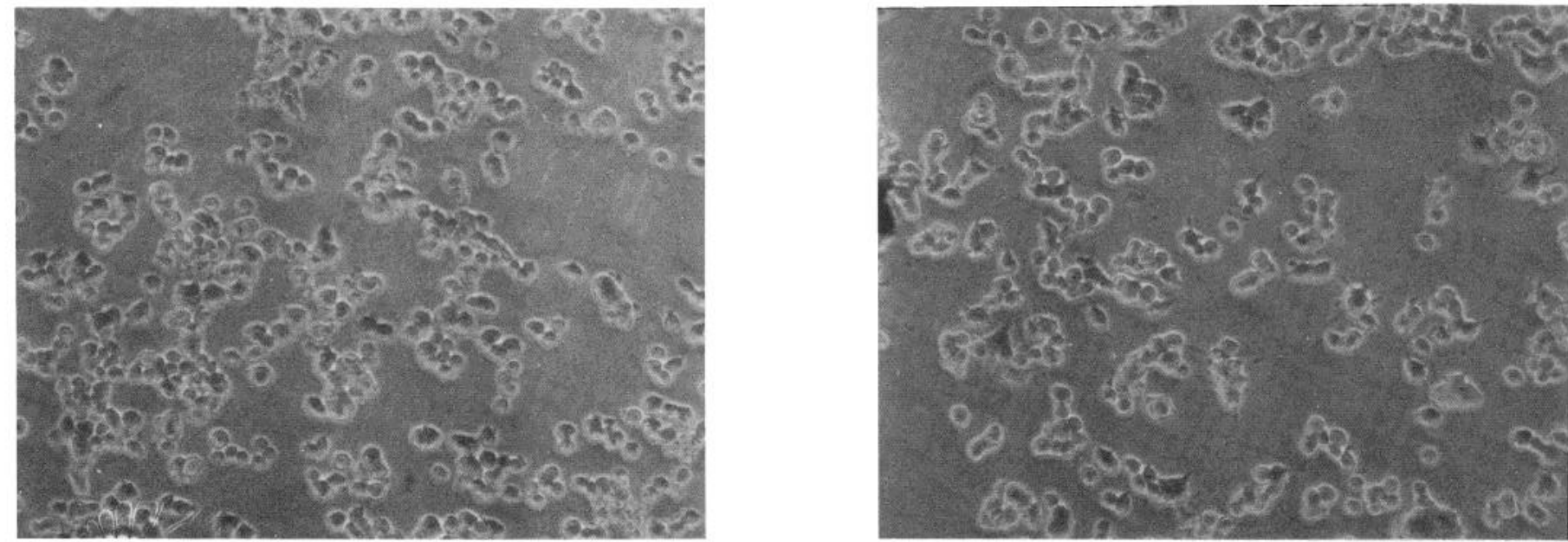

\section{0}
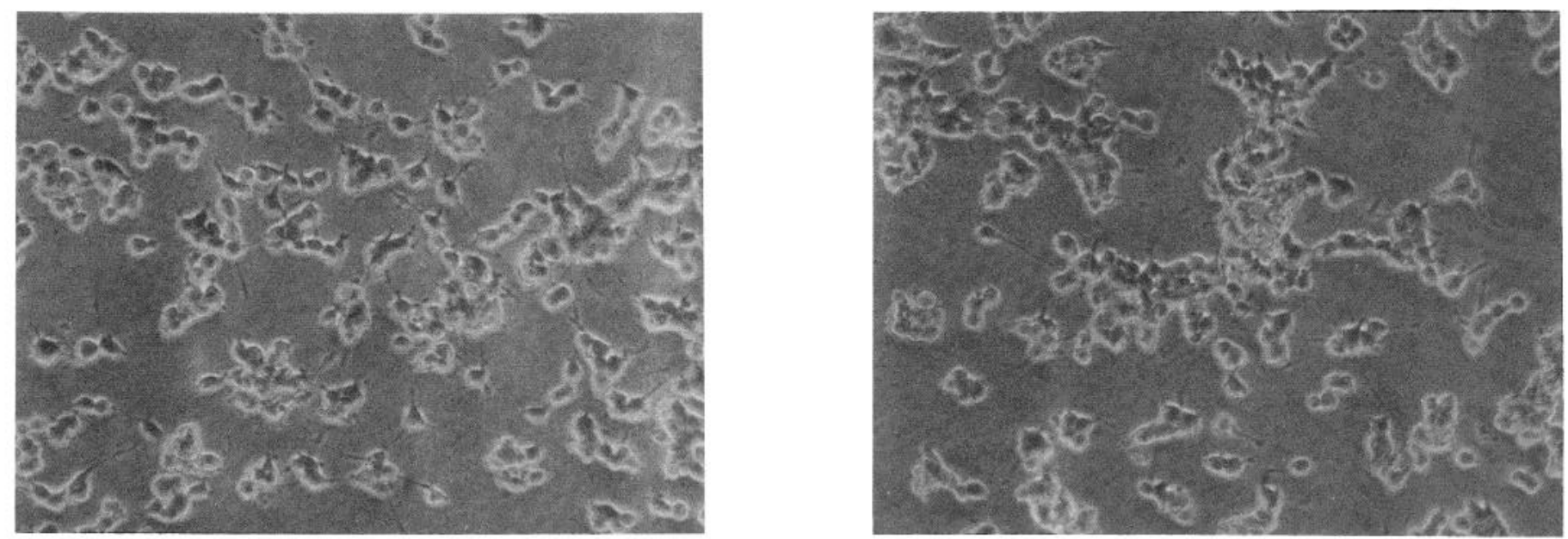

\section{5}

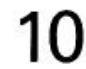

Figure 9. Process outgrowth in PC12 cells induced by highly purified FGF. Cells were treated for $72 \mathrm{hr}$ with indicated concentrations, in nanograms per milliliter, of highly purified pituitary FGF. Culture medium containing factor was changed every other day.

It is of interest that FGF provides a new tool with which to dissect the morphological, biochemical, and functional changes these cells undergo. It will be interesting to study whether the differences in the actions of the two peptides can shed some light on which of the intracellular changes are important for the subsequent phenotypic alterations. The PC12 tool may also provide a useful model system with which to pursue studies on the mode of action and biological function of FGF itself. Finally, these observations suggest that experiments on the role of FGF in the biology of other neural crest-derived cells might be in order.

\section{References}

Bocchini, V., and P. U. Angeletti (1969) The nerve growth factor: Purification as a 30,000 molecular weight protein. Proc. Natl. Acad. Sci. U. S. A. 64: 787-794.

Boonstra, J., W. H. Moolenaar, P. H. Harrison, P. Moed, P. T. van der Saag, and S. W. DeLaat (1983) Ionic responses and growth stimula- tion induced by nerve growth factor and epidermal growth factor in rat pheochromocytoma (PC12) cells. J. Cell Biol. 97: 92-98.

Bradford, M. M. (1976) A rapid and sensitive method for the quantitation of microgram quantities of protein using the principle of protein-dye binding. Anal. Biochem. 72: 248-254.

Bradshaw, R. A. (1978) Nerve growth factor. Annu. Rev. Biochem. 47: 191-216.

Burstein, D. E., and L. A. Greene (1978) Evidence for both RNA synthesis-dependent and -independent pathways in stimulation of neurite outgrowth by nerve growth factor. Proc. Natl. Acad. Sci. U. S. A. 75: 6059-6063.

Burstein, D. E., and L. A. Greene (1983) Nerve growth factor has both mitogenic and anti-mitogenic action. Dev. Biol. 94: 477-482.

Dichter, M. A., A. S. Tischler, and L. A. Greene (1977) Nerve growth factor-induced increase in electrical excitability and acetylcholine sensitivity of a rat pheochromocytoma cell line. Nature 268: 501504.

End, D., N. Tolson, M. W. Yu, and G. Guroff (1982) Effects of 12-Otetradecanoyl-13-acetate (TPA) on rat pheochromocytoma (PC12) cells: Interactions with epidermal growth factor and nerve growth factor. J. Cell. Physiol. 111: 140-148. 
End, D., N. Tolson, S. Hashimoto, and G. Guroff (1983) Nerve growth factor-induced decrease in the cell-free phosphorylation of a soluble protein in PC12 cells. J. Biol. Chem. 258: 6549-6555.

Gospodarowicz, D. (1974) Localization of a fibroblast growth factor and its effect alone and with hydrocortisone on $3 \mathrm{~T} 3$ cell growth. Nature 249: 123-127.

Gospodarowicz, D. (1975) Purification of fibroblast growth factor from bovine pituitary. J. Biol. Chem. 250: 2515-2520.

Gospodarowicz, D., H. Bialecki, and G. Greenberg (1978a) Purification of fibroblast growth factor activity from bovine brain. J. Biol. Chem. 253: $3736-3743$.

Gospodarowicz, D., G. Greenberg, H. Bialecki, and B. Zctter (1978b) Factors involved in the modulation of cell proliferation in vivo and in vitro: The role of fibroblast and epidermal growth factors in the proliferative response of mammalian cells. In Vitro 14: 85-118.

Gospodarowicz, D., J. Cheng, and M. Lirette (1983) Bovine brain and pituitary fibroblast growth factors: Comparison of their abilities to support the proliferation of human and bovine vascular endothelial cells. J. Cell Biol. 97: 1677-1685.

Greene, L. A., and J. C. McGuire (1978) Induction of ornithine decarboxylase by nerve growth factor dissociated from effects on survival and neurite outgrowth. Nature 276: 191-194.

Greene, L. A., and G. Rein (1977) Synthesis, storage, and release of acetylcholine by a noradrenergic pheochromocytoma cell line. Nature 268: $349-351$.

Greene, L. A., and E. M. Shooter (1980) The nerve growth factor. Annu. Rev. Neurosci. 3: 353-402.

Greene, L. A., and A. S. Tischler (1976) Establishment of a noradrenergic clonal line of rat adrenal pheochromocytoma cells which respond to nerve growth factor. Proc. Natl. Acad. Sci. U. S. A. 73: 2424-2428.

Greene, L. A., and A. S. Tischler (1982) PC12 pheochromocytoma cultures in neurobiological research. In Advances in Cellular Neurobiology, S. Fedoroff and L. Hertz, eds., Vol. 3, pp. 373 414, Academic Press, Inc., New York.

Greene, L. A., D. E. Burstein, and M. M. Black (1982) The role of transcription-dependent priming in nerve growth factor promoted neurite outgrowth. Dev. Biol. 91: 305-316.

Gunning, P. W., G. E. Landreth, M. A. Bothwell, and E. M. Shooter (1981) Differential and synergistic actions of nerve growth factor and cyclic AMP in PC12 cells. J. Cell Biol. 89: 240-245.

Guroff, G. (1984) PC12 cells as a model of neuronal differentiation. In Cell Culture in the Neurosciences, J. Bottenstein and G. Sato, eds., Plenum Press, New York, in press.

Guroff, G., G. Dickens, and D. End (1981a) The induction of ornithine decarboxylase by nerve growth factor and epidermal growth factor in PC12 cells. J. Neurochem. 37: 342-349.

Guroff, G., G. Dickens, and D. End (1981b) The action of adenosine analogs on PC12 cells. J. Neurochem. 37: 1431-1439.

Halegoua, S., and J. Patrick (1980) Nerve growth factor mediates phosphorylation of specific proteins. Cell 22: $571-581$.

Heumann, R., M. Schwab, and H. Thoenen (1981) A second messenger required for nerve growth factor biological activity? Nature 292: 838840 .

Hsueh, A. W., T. H. Welsh, and P. B. C. Jones (1981) Inhibition of ovarian and testicular steroidogenesis by epidermal growth factor. Endocrinology 180: 2002-2010.

Huang, K. -P., and J. C. Robinson (1976) A rapid and sensitive assay method for protein kinase. Anal. Biochem. 72. 593-599.

Huff, K., D. End, and G. Guroff (1981) Nerve growth factor-induced alteration in the response of $\mathrm{PC} 12$ pheochromocytoma cells to epidermal growth factor. J. Cell Biol. 88: 189-198.

Johnson, C. D., and R. L. Russell (1975) A rapid, simple radiometric assay for cholinesterase, suitable for multiple determinations. Anal. Biochem. 64: 229-238.

Johnson, L. K., J. D. Baxter, I. Vlodavsky, and D. Gospodarowicz (1980) Epidermal growth factor and expression of specific genes: Effects on cultured rat pituitary cells are dissociable from the mitogenic response. Proc. Natl. Acad. Sci. U. S. A. 77: 393-398.

Laemmli, U. K. (1970) Cleavage of structural proteins during the assembly of the head of bacteriophage T4. Nature 227: 680-685.

Lowry, O. H., N. J. Rosebrough, A. L. Farr, and R. J. Randall (1951) Protein measurement with the Folin phenol reagent. .I. Riol. Chem 193: 265-275.

Lucas, C. A., D. Edgar, and H. Thoenen (1979) Regulation of tyrosine hydroxylase and choline acetyltransferase activities by cell density in PC12 pheochromocytoma clonal cell line. Exp. Cell Res. 121: 79 86.

Lucas, C. A., A. Czlonkowska, and G. W. Kreutzberg (1980) Regulation of acetylcholinesterase by nerve growth factor in the pheochromocytoma PC12 cell line. Neurosci. Lett. 18: 333-337.

O'Farrell, P. H. (1975) High resolution two-dimensional electruphoresis of proteins. J. Biol. Chem. 250: 4007-4021.

Oka, T., and J. W. Perry (1976) Studies on regulatory factors of ornithine decarboxylase activity during development of mouse mammary epithelium in vitro. J. Biol. Chem. 251: 1738-1744.

Pegg, A. E., and H. G. Williams-Ashman (1968) Biosynthesis of putrescine in the prostate gland of the rat. Biochem. J. J08: 533-539.

Rieger, F., M. L. Shelanski, and L. A. Greene (1980) The effects of nerve growth factor on acetylcholinesterase and its multiple forms in cultures of rat PC12 pheochromocytoma cells: Increased total specific activity and appearance of the $16 \mathrm{~S}$ molecular form. Dev. Biol. 76: 238-243.

Schubert, D., S. Heinemann, and Y. Kidokoro (1977) Cholinergic metabolism and synapse formation by a rat nerve cell line. Proc. Natl. Acad. Sci. U. S. A. 74: 2579-2583.

Seeley, P. J., A. Rukenstein, J. L. Connolly, and L. A. Greene (1983) Methylation inhibitors block responses of $\mathrm{PC} 12$ pheochromocytoma cells to nerve growth factor (NGF) but not to epidermal growth factor (EGF). Soc. Neurosci. Abstr. 9: 841.

Togari, A., D. Baker, G. Dickens, and G. Guroff (1983) The neuritepromoting effect of fibroblast growth factor on PC 12 cells. Biochem. Biophys. Res. Commun. 114: 1189-1193.

Tuszynski, G. P., L. Knight, J. R. Piperno, and P. N. Walsh (1980) A rapid method for removal of $\left({ }^{225}\right.$ I)iodide following iodination of protein solutions. Anal. Biochem. 106: 118-122.

White, B. A., and F. C. Bancroft (1983) Epidermal growth factor and thyrotropin-releasing hormone interact synergistically with calcium to regulate prolactin mRNA levels. J. Biol. Chem. 258: 4618-4622.

$\mathrm{Yu}, \mathrm{M}$. W., N. Tolson, and G. Guroff (1980) Increased phosphorylation of specific nuclear proteins in superior cervical ganglia and $\mathrm{PC} 12$ cells in response to nerve growth factor. J. Biol. Chem. 255: 1048110492 . 